報 文

\title{
酵素修飾ゼラチンを用いて調製した高粘性 エマルジョンの品質評価
}

\author{
島田淳子*・矢沢悦子*・荒井綜 - ${ }^{* *}$
}

\section{Quality Evaluation of a Concentrated Emulsion Prepared with Enzymatically Modified Gelatin}

\author{
Atsuko Shimada*, Etsuko Yazawa* and Soichi Arai** \\ * Department of Food and Nutrition, Ochanomizu University, Bunkyo-ku, Tokyo 112 \\ ** Department of Agricultural Chemistry, The University of Tokyo, Bunkyo-ku, Tokyo 113
}

\begin{abstract}
L-Leucine $n$-dodecyl ester was covalently attached to gelatin by modification with papain under a specific condition. The product linked $0.44 \%$-leucine $n$-dodecyl ester on weight basis and showed a high degree of surfactancy permitting emulsificaton of soybean oil. This surfactant was used as an ingredient for preparing a mayonnaise-simulated emulsion, with the result that the emulsion resembled commercial mayonnaise items with respect to oil-particle size distribution, texturometric parameters on hardness and adhesiveness, viscometric flow behavior, and sensory scores. The use of secondary ingredients including seasonings together with the enzymatically modified gelatin, had no adverse effect on the emulsion formation. Also, the emulsion prepared with this surfactant was characterized by a low degree of drainage formation during storage and found to be stable over a long period of time.
\end{abstract}

(Received Aug. 5, 1981)

フミノ酸エステル存在下の特殊条件でタンパク質をパ パイン処理することにより，そのアミノ酸エステルをべ プチド粭合状に付加させることができる。この方法を 用いて親水性タンパク質に疎水性ロイシンドデシルエス テルを共有付加させると, 两親媒性棈造をむつタンパク 質状界面活性郕を調製することができる2) 5)。筆者ら は，ゼラチンおよび魚肉タンパク質濃縮物に本法を適用 することにより，疑塑性流動を示するのから，粘弾性の あるゲル状のものまで幅広い物性をるつェマルジョンを 調製するに適したタンパク質状乳化剂を得た。今回は, ゼラチンにロイシンドデシルェステルを共有付加して得 られた釈化剤-以後 EMG (enzymatically modified gelatin）と記すーを用いて高粘度エマルジョンを試作し，
そのマヨネーズ類似物としての品質評価を行なうととに より，EMGを全卵あるいは卵黄の代替物としてマヨネ ーズ状製品の調製に使用しうることが明らかになったの で報告する。

\section{試料および方法}

\section{1. タンパク質状界面活性都の調製}

既報28)に述べた方法に従って調製した。すなるち， ゼラチン (関東化学) $100 \mathrm{~g}$ に対し, $10 \mathrm{mML-システィ}$ ン含有の $1 \mathrm{M}$ 炭酸緩衝溶液 (pH 9) を $200 \mathrm{ml}$ 加允, と れに L-ロイシン $n$-ドデシルエステルを最終浱度が 0.1 mole $/ 100 \mathrm{ml}$ となるように添加した。パハイン（マイル ス社, $1.16 \times 10^{-2}$ 単位) $1 \mathrm{~g}$ を加え, $37^{\circ} \mathrm{C}$ で 15 分間イン

* お茶の水女子大学家政学部食物学科（矛112 東京都文京区大挥 2-1-1)

** 東京大学農学部農芸化学科（干113 東京都文京区弥生 1-1-1） 
キニベートした後，反応液を十分に流水透析して低分子 群を除去し，高分子画分を湅結乾燥して EMG の粉末を 得た。このむののアミノ酸組成は Asp 5.8\%，Thr 1.6 $\%$, Ser $2.9 \%$, Glu $8.6 \%$, Gly $22.9 \%$, Ala $7.7 \%$, Val $1.7 \%$, Met $0.5 \%$, Ile $1.1 \%$, Leu $6.0 \%$, Tyr $0.9 \%$, Phe $1.9 \%$, Lys $3.7 \%$, His $0.6 \%$, Arg $7.0 \%$, Pro 13.4\%, Hyp 13.4\% で, SDS-ポリフクリルフミドゲル 電気泳動法帛によって推定した分子量分布は MW 10000 以下 $23.1 \%$, MW 10000-MW $2000047.7 \%$, MW 20 000-MW 30000 20.5\%, MW 30 000-MW 400006.3 $\%$, MW 40000 以上 $2.4 \%$ ，ガスクロマトグラフィー4) によって求た $n$-ドデシル含量性 $0.44 \%$ である。

なお，対照として全卵および卵黄，そして Tween-60 (ボリオキシェチレンソルビタンモノステフレート)を 用いた。

2. マヨネーズおよひ類似の高粘度エマルジョンの調 製

市販マョネーズの一般組成に準し，大豆油（昭和産業 株式会社), $3.5 \%$ 酷酸水溶液, 塩化ナトリウムの重量混 合比を $6: 1: 0.1$ に設定した。乳化用カップに $3.5 \%$ 酶酸を $10 \mathrm{ml}$ ，塩化ナトリウムを $1 \mathrm{~g}$ 入れ，0.5 3.0\% (W/W) の裖度となるように EMG を加光, $40^{\circ} \mathrm{C}$ に保 温して溶解した後 $20^{\circ} \mathrm{C}$ になるまで放置した。これに $20^{\circ} \mathrm{C}$ の大豆油 $60 \mathrm{~g}$ を $20 \mathrm{ml} / \mathrm{min}$ の速度で滴下しつつ, ホモゲナイザーを用いて $6000 \mathrm{rpm} て ゙ 10$ 分間㹂拌した。

同じ方法で全卵マヨネーズおよび卵黄マヨネーズを調 製した。全卵および卵黄の水分含量を考虑して，水分と 塩化ナトリウムの比率が $1: 0.1$ となるようにし，油と 水分の比率㹥全卵を用いる場合 $3: 1$ から $6: 1$ まで, 卵黄を用いる場合 $2: 1$ から $4: 1$ までとした。すなか 方，全卵 $5 \mathrm{~g} ， 3.5 \%$ 酶酸 $5 \mathrm{~g}$, 塩化ナトリウム $0.875 \mathrm{~g}$ に大豆油を $26.3 \mathrm{~g}, 35.0 \mathrm{~g}, 43.8 \mathrm{~g}$ および $52.5 \mathrm{~g}$ 加党 た。卵黄については卵黄 $5 \mathrm{~g}, 3.5 \%$ 酶酸 $5 \mathrm{~g}$, 塩化ナト リウム $0.75 \mathrm{~g}$ に大豆油 $15 \mathrm{~g}, 22.5 \mathrm{~g}$ および $30 \mathrm{~g} を そ$ れぞれ加えてマヨネーズとした。

なお，市販マヨネーズ 4 種（キニーピー株式会社，味 の素株式会社, Beatrice Food 社, BEST FOOD 社) も参考試料として用いた。

3. 油滴粒度分布およびエマルジョンの物性測定

マヨネーズ類および類似メマルジョンに拈ける粒度分 柯はコールターカウンター（株式会社日科機，モデル BZ) を用い，対数確率紙にプロットした油脂球の累皘体 稍一バセントから，平均粒子径と幾何学標準偏差を算出 した。エマルジョンの硬さおよび付着性はテクスチュロ
メーター(株式会社全研, GTX-2 型)を用いて測定し,そ れぞれ $\mathrm{kg}$ 単位およびテクスチニロメーター単位(T.U.) で表わした。またエマルジョンの流動特性をコーンプレ 一ト型粘度計（東京計器株式会社, EHD 型) で測定し, Herschel-Bulkley の流動方程式 ${ }^{n}$ ) 降伏值 Py (dyn/ $\mathrm{cm}^{2}$ ), 粘性定数 $\mathrm{K}$ (poise)，流動性指数崖算出した。

\section{4. 安定性の測定}

マヨネーズ約 $7 \mathrm{~g}$ をスピョツに入れ, $5000 \mathrm{rpm}, 3$ 分 間遠心分離し，分離してきた油と水を注射器で採取して 秤量しるとの重量に対する重量パーセントで示した。

5. 官能検查

お茶の水女子大学調理学研究室員 30 名をパネルとし, 試料 $3 \sim 4 \mathrm{~g}$ を口に入れたさいの，かたさとなめらかさ を評点法より評価した。

\section{結果}

1. マヨネーズおよび類似の高粘度エマルジョンの特 性

EMG 拉よび Tween-60 を用いて調製した高粘性エ マルジョン，全卵および卵黄安用いて調製したマヨネー ズそとして 4 種類の市販マヨネーズについて測定した各 種性状および官能特性を表 1 亿まとめた。

油滴の平均直径は， EMG の使用量を $0.5 \%$ から $3 \%$ に增加させると $10.0 \mu \mathrm{m}$ から $2.68 \mu \mathrm{m}$ に低下した。市

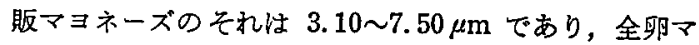

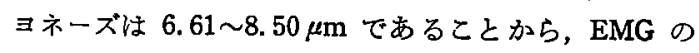
使用量を $1 \%$ 以上にすれば，市販マヨネーズまたは全卵 マヨネーズに匹敵した平均油滴直径を，さらに $3 \%$ 使用 すれば卵黄マヨネーズと同等の平均油滴直径をもつエマ ルジョンが得られることがわかった。また，Tween-60 で調製したエマルジョンは，同量の EMGで調製したエ マルジョンと比較して平均油滴值径はかなり大きかっ た。油滴直径の幾何学的標準偏差は, 平均油滴直径が大 きいむのほど大きな値となる傾向にあった。EMGを 3 \%使用して調製したエマルジョンの幾何学的標準偏差は 1.28 で, 卵黄マヨネーズのそれよりる小さく, 油滴サ イズの一様なエマルジョンであることが認められた。

テクスチュロメーターにより硬さを測定したところ, EMG 使用エマルジョンはその使用量が增すにしたが い, 硬さは $0.87 \mathrm{~kg}$ 単位加ら $2.38 \mathrm{~kg}$ 単位へと堌加し たが，Tween-60使用エマルジョンでは使用量は硬さに 影響せず，1\%使用でる EMG 1\%使用エマルジョンよ り顕著にやわらかかった。全卵マヨネーズは，市販品の 配合割合に準じ，油の割合のみ变えることにより調製し 


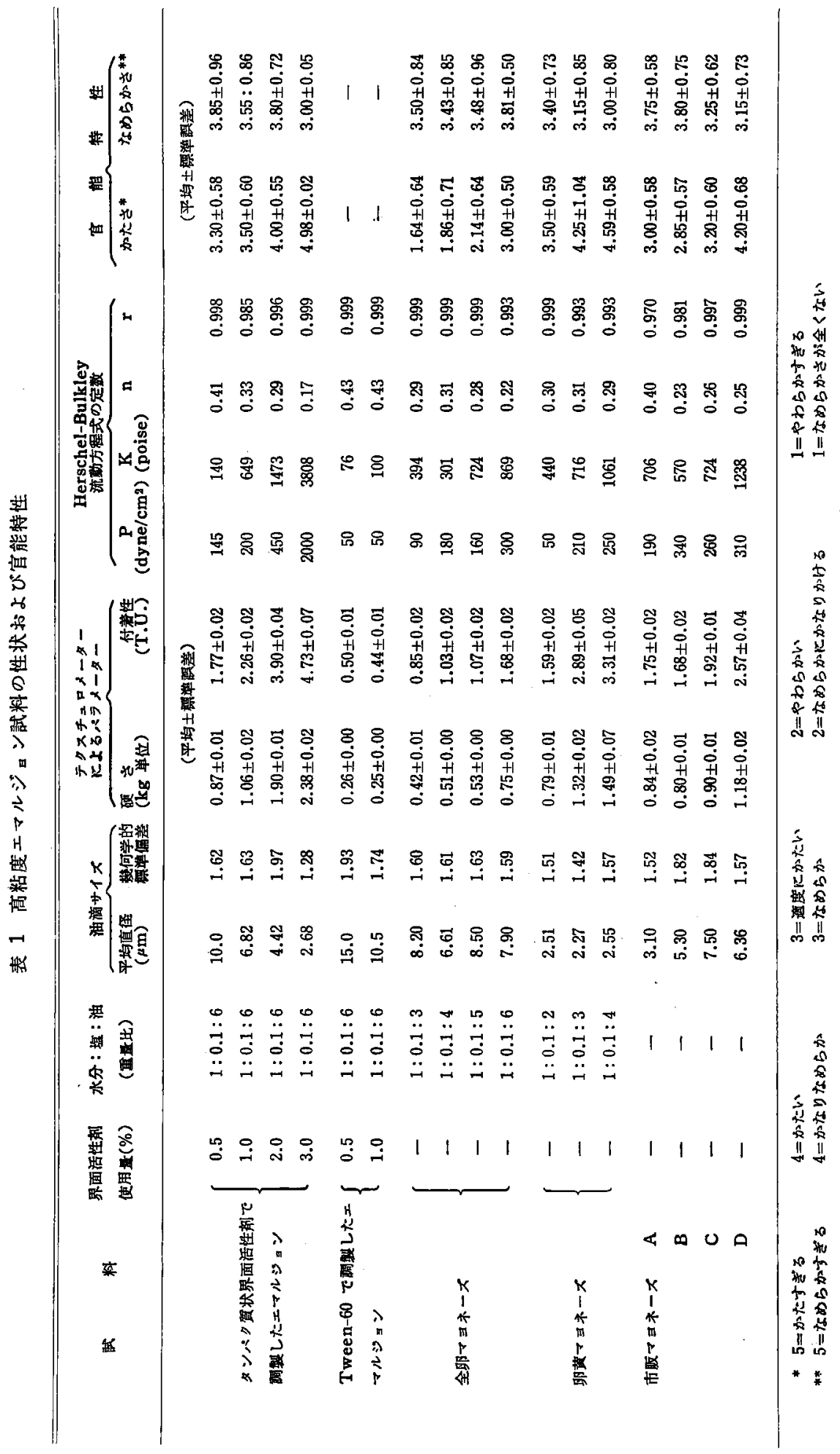


裴 2 高粘性エマルジョンの物性におよほす主材料濃度および副材料の影響

\begin{tabular}{|c|c|c|c|c|c|c|}
\hline & \multirow{2}{*}{ 因 } & \multirow{2}{*}{$\begin{array}{c}\text { 使用是 } \\
(\%) \\
(\%)\end{array}$} & 硬 & \multirow[t]{2}{*}{ さ } & 付 音 & \multirow[t]{2}{*}{ 性 } \\
\hline & & & 平均值 (kg 肾位) & & 平均值 (T.U.) & \\
\hline A & 酷酸眚度 & $\begin{array}{l}1.75^{b} \\
3.50\end{array}$ & $\begin{array}{l}0.990 \\
1.061\end{array}$ & $\mathrm{P}<0.01$ & $\begin{array}{l}2.106 \\
2.255\end{array}$ & \}$P<0.01$ \\
\hline B & 㙋 & $\begin{array}{l}0.7 \mathrm{a} \\
1.4\end{array}$ & $\begin{array}{l}1.033 \\
1.019\end{array}$ & $P>0.05$ & $\begin{array}{l}2.179 \\
2.182\end{array}$ & $P>0.05$ \\
\hline $\mathrm{c}$ & カシシ粉 & $\begin{array}{l}0 \\
1.0 \mathrm{a}\end{array}$ & $\begin{array}{l}0.849 \\
1.203\end{array}$ & $P<0.01$ & $\begin{array}{l}1.829 \\
2.533\end{array}$ & $\{P<0.01$ \\
\hline D & コショウd & $\begin{array}{l}0 \\
0.1^{\mathrm{a}}\end{array}$ & $\begin{array}{l}0.960 \\
1.091\end{array}$ & $\mathrm{P}<0.01$ & $\begin{array}{l}2.048 \\
2.314\end{array}$ & $\{P<0.01$ \\
\hline $\mathbf{E}$ & 砧 糖 & $\begin{array}{l}0 \\
1.0 \mathrm{a}\end{array}$ & $\begin{array}{l}1.029 \\
1.023\end{array}$ & $P>0.05$ & $\begin{array}{l}2.199 \\
2.163\end{array}$ & $\{P>0.05$ \\
\hline F & クルタミン酸ンーダ & $\begin{array}{l}0 \\
0.1 \mathrm{a}\end{array}$ & $\begin{array}{l}1.034 \\
1.018\end{array}$ & $P>0.05$ & $\begin{array}{l}2.205 \\
2.156\end{array}$ & $P>0.05$ \\
\hline & $B \times D$ & & & $P<0.05$ & & $P<0.05$ \\
\hline & $A \times E$ & & & $P<0.01$ & & $P>0.05$ \\
\hline
\end{tabular}
a. 高粘性エマルション全笽に刘与る百分率
b. 使用酰酸漫度
c. エスビー食㫛铢式会社
d. 八ウス食品工業株式会社

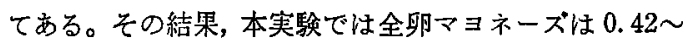
$0.75 \mathrm{~kg}$ 単位, 卵黄マヨネーズは $0.79 \sim 1.49 \mathrm{~kg}$ 単位の 硬さのむのが得られ，EMG 使用エマルジョンは全卵マ ヨネーズより硬く，卵黄マヨネーズと同等るしくはそれ 以上の硬さであった。また，EMG 0.5 1\% 使用で市販 マヨネーズと同等の硬さが得られた。このことは宣能検 查によってる裹づけられた。食品材料をあえるときの “まといつき”に対応するバラメーターである付着性に ついても硬さについて得られたと同栐の傾向が不られ た。

次に，流動特性のうち保形性に関係するパラメーター である降伏值 $\mathrm{P}$ は， EMG $0.5 \%$ 使用で $145 \mathrm{dyn} / \mathrm{cm}^{2}$, $3 \%$ 使用で $2000 \mathrm{dyn} / \mathrm{cm}^{2}$ と著しく増大し，粘性定数 $\mathrm{K}$ む 140 poise から 3808 poise と同様に增大した。また, 絞り出しやすさと相関するパラメーターである流動性指 数 $n$ は $0.41 \sim 0.17$ と顕著に減少した。全卵マヨネーズ, 卵黄マヨネーズおよび市販マヨネーズの流動特性值とほ 活同等のそれは，EMG 它 0.5〜2\% 使用することによ って得られた。それに対し，Tween-60 使用エマルジョ ンは使用量を增加させても EMG 使用エマルジョンに匹 敵するものは得られなかった。

評点法により評洒したなめらかさの目能検查の結果 は,“なめらか”から“かなりなめらがの間であった。 以上より，EMG を 0.5 1\%の範围で使用することに より，物性的にも官能的にもマヨネーズ類と同等の性状 をるつェマルジョンを作ることができ，さらに油滴のサ イズにおいては，使用量 $1 \%$ 以上，好ましくは使用量 $3 \%$ で卵黄マヨネーズに匹敞する優れた高粘性エマルジ
ヨンが調製され得ることがわかった。

\section{2. 主材料濃度および副材料の影響}

マヨネーズに普通用いられる副材料化より乳化が阻箁 されるか否か，また䣷酸や食塩濃度により影響を受け るか否かを， $\mathrm{L}_{16}$ の直交表を用いて検討した。試料は， EMG $0.5 \%$ 使用した高粘性エマルションとした。 予備实験より，マヨネーズの物性に影響する可能性のあ る主効果 6 因子と交互作用 2 種を検定し得るよう計画し た。各因子について，テクスチュロメトリーによって硬 さ (kg 単位) と付着性 (T.U.) を測定し，水準ごとの 平均値を求め，分散分析を行なった。その結果を表 2 に記す。カラシ粉の添加はエマルジョンの硬さと付着性 の両者を 1.4 倍程度にまで増加させた。またコショウの 添加は，硬さ，付着性を 1.1 倍程度增加させた。他の副 材料は影響を与觉なかった。酢酸濃度は，3.5\%の方が 1.75\%のものより，硬さ，付着性ともに大であった。

以上より，EMG を实際のマヨネーズ製造汇用いるさ い, 副材料や材料濃度により物性值汇多少の変動はみら れるむのの，高粘性エマルジョンの形成を大きく阻害京 ることのないことが確認された。

3. EMG から調製した高粘性エマルジョンの安定性 各種マヨネーズ試料および類似の高粘性エマルジョン を試料ビン（ポリエチレン製， $30 \mathrm{ml}$ 容器）に約 $20 \mathrm{~g}$ 充 填して密閉し，市販マヨネーズのシェルフライフを考愿 して $20^{\circ} \mathrm{C}$ に 5 ケ月間保存し，保存前後の安定性を比較し た。結果老 3 に記す。EMG $0.5 \%$ 使用のエマルショ ンは, 貯蔵前から分離水を生じ, 5 ケ月保存後では一層不 安定なとった。Tween-60を $0.5 \%$ 使用したェマルジ 
表 3 乳化杪の央類と高粘性エマルジョンの 貯藏安定性 ${ }^{2}$

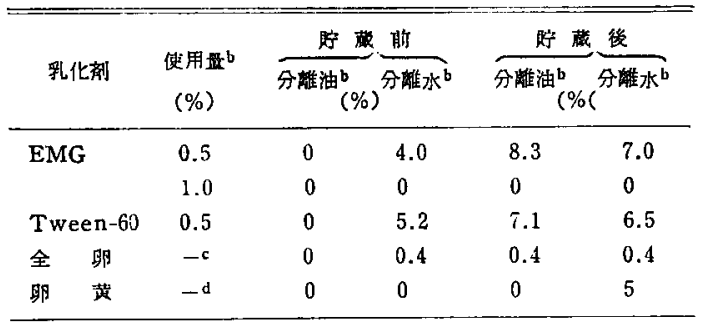

a. $20^{\circ} \mathrm{C}, 5$ ケ

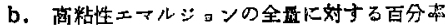

c. 水分: 塩: 油=1:0.1:6

d. 水分: 墥: 油=1:0.1:2

ョンむ同様であり，全卵マョネーズもやや不安定であっ た。しかしEMG 1\% 使用エマルジョンは 5 ケ月保存後 む, 卵黄マヨネーズと同棑水分注全く分唯しなかった。

\section{考察}

マヨネーズは $\mathrm{O} / \mathrm{W}$ 型のエマルジョンである。一般 に, O/W 型ェマルジョンにおいては, W/O 型ェマル ジョンにおけるよりも HLBの高い乳化削が必要とされ る。しかし，市販の脂質系乳化绪は蕉糖脂肪酸エステル の一部を除き HLB が低い。また，率煻脂肪酸エステル は酸に溶けにくく，このことからマヨネーズ様エマルジ ョンには卵黄に代わる釈化刘のないのが実情である。

本実験で明らかなように，EMG が良好な O/W 型エ マルジョンを形成したのは，マヨネーズ様食品への応用 可能性が高いことを示している。マヨネーズにとって必 要な性質は，まず油を細かく分散し，安定なェマルジョ ンを作ることである。また口に入れたときにはある程度 のかたさがあり，食品と混合するとき，すなわちずり速 度它かけたときには流動して食品材料に十分ゆきかた り，混合後は食品にまといついて流動しないことが必要 である。またそのェマルジョンが安定で長期の保存に耐 えることを必要とする。

EMG は，0.5\% 用いるだけで物性的には、市販マヨネ ーズ，全卵マヨネーズ，卵黄マヨネーズに匹敵する值を
示した(表 1)。しかし，0.5\% 添加試料は分散粒子の粒 径がやや大きく(衰 1)，安定性も悪い(表 3)。これらを 考虑すると，EMG $1 \%$ 使用することにより，物性的 にも官能的にるマヨネーズと同等でしかも安定な高粘性 エマルジョンを作ることができると言えよう。なお，同 じ程度に油脂が分散したエマルジョンの物性を比較する と, EMG からのェマルジョンは他の釈化戍からのそれ にくらべて，いずれも硬さ，付着性，降伏值および粘性 定数が大きい傾向にあった。特に Tween-60 のように マヨネーズ様物性を全く示さないるのとの対比が顕著で あった。一般に O/W 型エマルジョンは油相の割合が增 加すれば硬くなる。しかし，現在の食品工業では，一般 に低カロリー食指向の傾向にあり，マヨネーズ様ドレッ シングも油を減らし，その分を糊料で補う傾向にある。 上記の実騟結果は, EMG が乳化削として細かく分散さ せるばかりでなく，糊料の役割をも兼備し，マヨネーズ 㴍食品に対して極めて実用可能性の高い素材であること を示唆している。

終わりに，本実騟を行なうにあたり御協力頂きました お茶の水女子大学家政学部, 系島みどり氏に感禹いたし ます。

\section{文献}

1) Yamashita, M., Arai, S., Imaizumi, Y., Amano, Y. and Fujmaki, M.: J. Agric. Food Chem., 27, 52 (1979).

2) Arai, S. and Watanabe, M.: Agric. Biol. Chem., 44, 1979 (1980).

3) Watanabe, M., Toyokawa, H. Shimada, A. and ARAI, S.: J. Food Sci., 46, 1467 (1981).

4) Watanabe, M., Shimada, A., Yazawa, E., Kato, T. and Arai, S.: J. Food Sci., 印刷中。

5) Watanabe, M., Shimada, A., Arai, S.: Agric. Biol. Chem., 45, 1621 (1981).

6) Shimada, A., Yazawa, E., ARaI, S.: Agric. Biol. Chem., 46, 173 (1982).

7) RAO, M.A.: J. Texture Studies, 8, 135(1977). (㗁和 56 年 8 月 5 日受理) 